\title{
Organized and informal recycling: social movements contributing to sustainability
}

\author{
J. Gutberlet \\ University of Victoria, Department of Geography, Canada
}

\begin{abstract}
A paradigm shift recognizing the contribution of inclusive resource recovery to global sustainability is urgently needed. Informal and organized community recycling create social, economic and environmental benefits. Inclusive door-todoor recycling builds awareness for responsible consumption, redirects resources, diminishes environmental impacts from waste disposal and most importantly it contributes to the generation and redistribution of income and hence can tackle poverty reduction. Gathering, separating and selling recyclables has become a survival strategy for the excluded population in most cities. Very few cities in the world have incorporated recycling cooperatives and associations in waste management and only few policies have been developed to support this approach. The few experiences, however, highlight that besides redirecting solid waste into production streams, recycling also builds citizenship and contributes to creating community. Despite these benefits to the environment and to the community at large the recyclers are usually disregarded. As a result of their marginalization, the full potential of the informal and organized recycling industry is not harnessed. Theory on governance, social economy and resource management provide the grounding for the definition of a new concept for inclusive waste management that goes beyond waste disposal addressing responsible consumption and global sustainability. The paper discusses experiences from Latin American recycling networks and case studies on innovative public policies in Brazil. Waste as a resource enhances global sustainability and locally creates job opportunities. Stigmatization and prejudices against the recyclers are to be overcome and the real environmental services provided by this population are yet to be fully recognised.
\end{abstract}

Keywords: resource recovery, community recycling, participatory management. 


\section{Introduction}

Innovative and more sustainable approaches in solid waste management are emerging in different parts of the world [1-3]. Participatory waste management means including those individuals that are already working with resource recovery, by performing activities known as binning (recovering recyclables from the garbage bin) or selective collection (highly structured, door-to-door collection of recyclables). Often the pressure for social change comes from below, from organized social movements and community initiatives. Sometimes, local governments embrace the idea of generating income and servicing the environment with organized recycling. Diadema, for example, is the first city in Brazil that pays recyclers for the service of door-to-door collection.

Worldwide the number of people whose livelihoods depend on the recovery of recyclable material out of the domestic waste stream is increasing. The collection, separation and recycling of these materials has become a widespread survival strategy for the unemployed in poor countries and is becoming a more widespread phenomena also in the North. These people represent the most disenfranchised and vulnerable part of the population, are informal and hence socially and economically excluded, and usually powerless in local policy and decision-making. In North America they are known as binners and in South America as Recuperadores, Recicladores, Catadores, Carrinheiros, etc. The picture is the same almost everywhere: many of them are homeless or live in precarious conditions, are malnourished and frequently exposed to occupational health risks. In North America scavenging through garbage bins remains an illegal activity and frequently confrontation with police can lead to harassment, fines or arrests. Humiliation and stigmatization towards binners and catadores is a common reaction from the community at large. It is still dismissed that the occupation provides the ability for this population to become independent, without having to resort to begging or crime, nor is the environmental benefit they provide with resource recovery valued (including climate change mitigation). Organized and community recycling initiatives have yet to be recognized as innovative tools for social justice and economic development.

The following three conceptual pillars support my reflections: governance, social economy, and resource management. Literature on governance and deliberative democracy [4-6], discuss new forms of partnerships between government and other stakeholders addressing the political and social contexts of waste management. Participation is a central characteristic of deliberative democracy and is understood as the procedure to ensure that "...the 'better argument', rather than coercion or manipulation, will determine the outcome" [7, page 24]. New ways of governance to overcome social, economic and political exclusion are necessary. Gerrometta et al. [8] highlight that civil society has a role to play in governance that can make valuable contributions to more cohesive communities. Social economy [9] brings the focus on collective over individual objectives and outcomes to the forefront and provides practical tools and examples for social economy that are applicable to waste management. Solidarity, reciprocity and autonomy are important common attributes among 
those practices. Finally, co-management defined by Carlsson and Berkes [10, page 65 ] as "... continuous problem-solving process, rather than a fixed state, involving extensive deliberation, negotiation and joint learning within problemsolving networks" informs about ways to implement inclusive resource management arrangements. My paper aims to discuss these three intertwined theoretical approaches to create a definition for inclusive waste management. I will provide insights to concrete experiences from Latin America.

\section{Where theory and praxis come together}

Generally there is not just one answer or one solution to a question. Our answers can be multiple layered and have various facets. Integrating different theoretical perspectives and empirical experiences in our search for more sustainable development seem to provide valuable insight. Sustainability first described in the Brundtland Report has evolved into a concept that integrates the following dimensions " ...the acknowledgement that available resources are not infinite, the recognition of the value of biodiversity [and cultural diversity], the demand for social equity, and a concern for long-term and intergenerational solidarity" [11, page 21]. Sustainability is a process rather than a set of well-defined objectives and Barkin [12] among others points to the fact that it is about people and local participation.

\subsection{New forms of governance}

True public participation in policy-making is more than just consultation. It requires transparent democratic processes, forums for deliberation and genuine participation of different stakeholders. Judith Petts [13] showcases deliberative processes in the particular context of waste management, and underlines the prominence of social responsibility and collective learning in this process. She describes how in the case of the UK community advisory committees and specific evaluating boards created by the local authorities have improved the solid waste management. Tim Forsyth [6] provides another example for deliberative public-private partnerships in the context of the Philippines and India. He affirms that allowing greater public participation in the policy formulation may become an important new form of local environmental governance. It seems that the process of deliberating in a participatory fashion can already cause positive spin-offs by itself. According to Weber [14] for example, empirical results underline that "...the extensive networking means that institutions and decision-makers who used to be inaccessible to many in the community.... are now only a phone call away because of the trust that networking has created" [14, page 198].

The literature describes different forms of co-governance. The essential element in different forms of co-governance is that interacting parties (groups, stakeholders) have something in common to pursue. Interrelations among the parties are based on the recognition of inter-dependencies. This is often also called multi-stakeholder approach. "This governance approach focuses on the interactions taking place between governing actors within social-political 
situations" [15, page 7]. "Co-governance in its varying appearance may be an answer, a reaction to, or an expression of what [the author sees] as a major societal development, the tendency towards growing societal interdependence and inter-penetration. Co-governance means utilizing organized forms of interactions for governing purposes" [15, page 97].

\subsection{Social and solidarity economy}

The term 'social economy' will be used here as a general overarching concept that represents a wide variety of other terms such as solidarity economy or social entrepreneurship, which themselves cover diverse features. "Social economy is so much embedded in historical, institutional and local contexts that it seems to escape generalization" [16, page 2049]. Here social justice issues and values, such as cooperation, redistribution, solidarity and reciprocity are brought to the forefront. Fraisse et al. [17] further stress the conceptual values with insisting in the term solidarity economy, designating “... all production, distribution and consumption activities that contribute to the democratization of the economy based on citizen commitments both at a local and global level' [17, page 4]. According to the Lima Declaration of 1997 “... it is built on a collective economic, political and social project that brings out about a new way of conducing politics and establishing human relationships on the basis of consensus and the activity of citizens"[18, page 91]. Here the focus is on income generation and wealth redistribution, social inclusion, as well as the praxis of solidarity and cooperation. Solidarity economy happens at the local, neighbourhood and community scale, however through networking it can also influence the global scale [19].

Curbing unemployment is a major target in social economy, and the main strategy is to value the local and creative workforce and to share assets and provide solidarity networks. Social practices, and skills are being developed through community-oriented social economy experiences. The recyclers' movements that are emerging in many countries in Latin America are occupying an important niche within this growing economy.

\subsection{Co-management of solid waste resources}

Co-management theory stems first from natural sciences, defined as sharing of responsibilities between government agencies and users or stakeholders for the well-being of the resource, for example to prevent overexploitation and to regulate fair access [20]. It translates into finding a shared understanding between government and community-initiated regulations. It is participatory rather than hierarchical; decentralized instead of centralized; and the process happens through active participation of the different parties in public policy making rather than just consultation. "By involving the knowledge of the users in governance, results will produce more adequate governing measures" [20, page 103]. This means "...users involved willingly accept the regulations as appropriate and consistent with their persisting values and worldviews" [20, page 104]. 
During their daily praxis, informal and organized recyclers have accumulated local knowledge regarding space and resources in the areas where they transit. They draw from valuable experiences that can also inform waste management and environmental education. Involving the population of informal and organized recyclers in the design and implementation of a waste management strategy can benefit the community and the local government. Inclusive recycling provides an opportunity for shared learning processes, where the government can also learn about poverty reduction [21]. 'Double loop learning' [22] has the potential to be transformative.

Inclusive waste management is an innovative strategy to tackle multiple environmental, economic and social problems. It means working with and for the local community in the sense of creating small and often diverse social economy experiences. It has so many positive spin-off effects, which do not occur in conventional mechanistic waste management schemes.

\section{Resource recovery: recent challenges and contributions}

Household waste in itself is a challenge. Waste is mostly perceived as an unwanted source and there is usually little awareness about the wider environmental implications once it is discarded. Introducing door-to-door selective waste collection systems makes households co-responsible in separating recyclable materials. There is potential for dialogue between recyclers and household members and education about minimizing waste and responsible consumption can take place.

Though it is not easy for an organized recycling system to become established from a bottom-up approach with a clear social and environmental commitment. The current capacity of the recyclers needs to be built and expanded, which is a lasting learning process. Often inclusive waste management is not conflict free and can also challenge existing power relations by transferring a voice to the recyclers in decision-making on solid waste management. There is economic value embedded in waste, particularly in some of the materials (aluminium, paper, cardboard and more recently certain plastics) and consequently large waste management corporations have a vested interest in these materials, as do small to medium sized middlemen. The quality of waste also follows a pattern of spatial distribution based on income and consumption levels; which means there are better and worse 'traplines' (defined routes that recyclers follow to collect material [23]). Large-scale waste management companies are keen on capturing this business. In many Latin American cities large corporations already dominate the market share. Today the prevailing waste management practices are still land-filling and incineration (and lately for energy generation purposes). Rarely cities invest in recycling. Most of the official recycling programs are not inclusive but rather exclude the ones that are already doing this job, jeopardizing their livelihoods.

Besides the institutional and entrepreneurial hurdles there are also serious issues that need to be addressed related to human dignity and the lack of respect attributed to binners. These and other findings are highlighted by a recent study 
completed in Victoria, Canada [24]. Three graduate students and 10 recyclers have conducted a livelihoods survey to shed light on the degree and extent of exclusion of this particular population, living in a rich city in North America (Figure 1). Most recyclers that were interviewed confirmed the fact that frequent stigmatization and harassment particularly by police and park officers were the most threatening aspects of their work. Until recently this fact was not reflected in the wide literature on homelessness [25]. The research points out that greater awareness among the general public would make a significant difference to the life of the recyclers. Public policies and educational campaigns can work with this knowledge to create the expected livelihood outcomes.

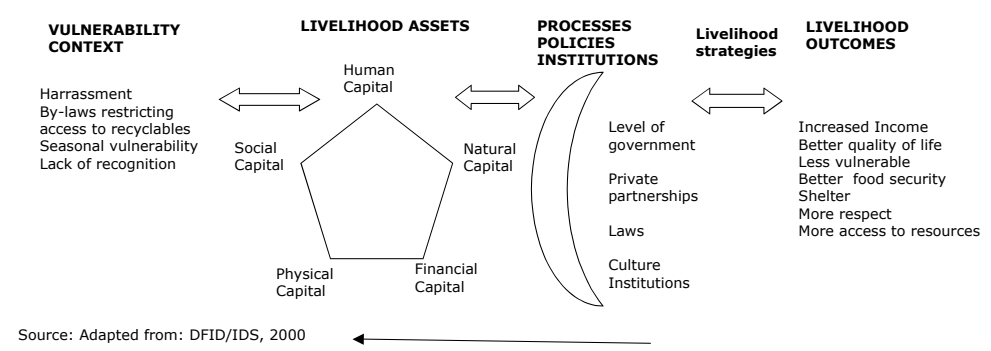

Figure 1: Livelihood situation of informal recyclers in Victoria, Canada.

There are few experiences in North America with social recycling enterprises. The bottle depot in Vancouver, United We Can (UWC), is one of the outstanding examples of social economy involving informal recyclers [23]. Here the binners get a fair price for their recovered bottles, they can access other services and are part of a community. The institutional framework, under which social enterprises like UWC operate, however, are sufficiently supported by the local government for them to thrive as they could.

In Brazil, as in many other Latin American countries, recycling cooperatives and associations are widespread. They often are more efficient in resource recovery than the official waste management programs. Only few local governments have embraced the cause and provide infrastructure support or pay for the service the recyclers perform. The city of Diadema in the southeast of Brazil is pioneering the redistribution of income through resource recovery. In December 2006, the city signed a legal agreement with the local association Associação Pacto Ambiental, a civil society organization of public interest (OSCIP) that congregates 6 recycling centers (one more under construction) with 62 members. As part of the Vida Limpa program on integrated waste management the members of Associação Pacto Ambiental are now rewarded for the quantity of recyclables they collect from the waste stream. The recyclers receive Reais $\$ 38$ per ton of recycled material, the same price the city would pay for its deposit at the landfill. This is the first step towards recognizing the environmental service provided by the recyclers.

The federal government of Brazil has passed a new legislation giving priority to recycling cooperatives and associations in municipalities contracting out 
selective waste collection services (federal law n ${ }^{\circ} 11.445,05$ January 2007). The law seeks to encourage social inclusion, particularly of those that were unemployed or suffer from any other disadvantage. The city of São Paulo has revised their recycling policy with a social-environmental selective collection program. São Paulo generates on average 15,000 tons of waste every day (household, construction, hospital and street sweeping waste), of which approximately half could be recycled. Today, the city collects regularly approximately 9,000 tons per day. There is potential for income generation and resource recovery, particularly since under the current official recycling program only 0.9 percent of the household waste is recycled. The federal government also created a secretary for solidarity economy with the mandate to assist social economy initiatives and to facilitate funding these activities. Recycling cooperatives and associations are well placed within this initiative.

\section{Recyclers' movement in Latin America}

In Brazil the recycling initiatives are organized into local groups (for example the Fórum Recicla São Paulo) or regional networks (for example the Rede CentralLeste). In 2004 the Movimento Nacional dos Catadores a national recyclers' movement was created, with the goal to expand inclusive waste management programs throughout the country and to integrate the struggle of the recyclers for local development, self-determination (autogestão) and control over the recycling production line. Today the category is integrated through a worldwide movement. The general societal changes proposed by the solidarity and social economy movement as described by Arruda (2006) also match with the goal set declared by the recyclers' movement. On the local and individual levels this means emancipation of the recyclers from subaltern social and economic situations, by expanding their own capacities. Providing working conditions that allow for the full development and use of the human capacities, based on habits of reciprocity and solidarity.

In early March 2008 the III. Latin American and the I. World Conference of recyclers will be hosted by the National Association of Recyclers of Colombia (ANR) in Bogotá. These conferences are organized by an international committee of organizations from the recyclers in India (KKPKP), Latin America (Network of Recycling Workers), the Global Network, Women in Informal Employment: Globalizing and Organizing (WIEGO), besides researchers from different countries.

Bringing together movements from different part of the word is a first step towards creating a Global Network of formal and informal recyclers. Among the principal objectives of the conference are: strengthening the organization and global connection of informal and organized recyclers (especially women) aiming at making their environmental and solid waste management contribution more visible. The current topics for debate are: 1) the Recycling production chain and the role of informal recyclers 2) public policies for inclusive and integrated solid waste management 3) risks of privatization for the work of 
informal recyclers 4) international agreements (e.g. the Kyoto Protocol and carbon credits), among others.

\section{Conclusion: recognizing opportunities to build capacity, to empower and to improve sustainability}

With inclusive resource recovery we have an opportunity to truly make a difference to social and environmental justice. It is time to wake up and see the sustainability opportunity given with inclusive waste management. Inclusive waste management is a proposal founded on innovative policies and where each individual is challenged with changes in lifestyle and values. It can help solve social, economic and environmental problems not only in the majority of countries in the South but also in the rich North.

Collaborative forms of local policy shaping enhance the decentralization of processes and devolve decision-making power and responsibility to the local levels of government. As a consequence, the governing body is closer to the people, and power is returned to the local level. Active participation of the involved stakeholders is essential to adequate resource management, and to deliberative democracy. Social movements are crucial to assure participation and bring different stakeholders into the arena. In many instances they are the motors to ensure a fair and equitable government and function as barometers to monitor impact and progress. In the South social movements play a critical role in establishing partnerships with governments and the business sector to address the issues the government alone cannot manage.

"If correctly understood, this resistance can become part of a broader effort to build a more just society; a society in which those who are traditionally left out could participate in reversing environmental damage and reducing the social costs of globalization" [12, page 5]. The national and global recyclers' movement has the potential to become a true resistance against the prevailing capitalistic and individualistic development trend. It is a movement of hope, valuing local knowledge and practices and allowing subaltern communities to become the subjects of their own development [26]. The principles of co-management, deliberative governance and social economy are informative to the proposed form of waste management [27].

The recyclers' movement is an experience of democratization of the economy from the grassroots level. It is a clear challenge to the establishment and an opportunity to generate a post-capitalist hegemony based on new forms of associations and networks of production and consumption from the local, regional, national to international levels, comparable to what Esteves [28] describes for social economy.

\section{References}

[1] Ali, M. \& Snell, M. Lessons from community-based initiatives in solid waste. London School of Hygiene \& Tropical Medicine, UK. WEDC, (Loughborough University, UK), 1999. 
[2] Gutberlet, J. Recovering resources: recycling citizenship: Urban poverty reduction in Latin America, Aldershot, Hampshire, UK, Ashgate, 2008.

[3] Medina, M., Scavenger cooperatives in Asia and Latin America, Resources Conservation and Recycling, 31, pp. 51-69, 2000.

[4] Luckin, D \& Sharp, L., Remaking local governance through community participation? The case of the UK community waste sector, Urban Studies, 41(8), pp. 1485-1505, 2004.

[5] Parkins, J. R. \& Mitchell, R. E., Public participation as public debate: a deliberative turn in natural resource management, Society and Natural Resources, 18, pp. 529-540, 2005.

[6] Forsyth, T., Building deliberative public-private partnerships for waste management in Asia, Geoforum 36, pp. 429-439, 2005.

[7] Zwart, I., A Greener Alternative? Deliberative Democracy Meets Local Government, Environmental Politics, 12(2), pp. 23-48, 2003.

[8] Gerometta, J., Haussermann, H \& Longo, G., Social Innovation and Civil Society in Urban Governance: Strategies for an Inclusive City, Urban Studies 42(11), pp. 2007-2021, 2005.

[9] Moulaert, F. \& Nussbaumer, J., Defining the Social Economy and its Governance at the Neighbourhood Level: A Methodological Reflection. Urban Studies, 42(11), pp. 2071-2088, 2005.

[10] Carlsson, L. \& Berkes F., Co-management: concepts and methodological implications, Journal of Environmental Management, 75, pp. 65-76, 2005.

[11] Raynaut, C., Zanoni, M., Ferreira, A. \& Lana, P., Sustainability: Where, when, for Whom? Past, present and future of a local rural population in a protected natural area (Guaraqueçaba, Brazil). Sustainability and Communities of Place, ed. C.A. Maida, Berghan Books: New York, pp. 2140, 2007.

[12] Barkin, D., Sustainability: The political economy of autonomous development, Organization and Environment, 11(1), pp. 5-32, 1998.

[13] Petts, J., Evaluating the Effectiveness of Deliberative Processes: Waste Management Case-studies, Journal of Environmental Planning and Management, 44(2), pp. 207-226, 2001.

[14] Weber, E.P., Bringing society back in: Grassroots ecosystem management, accountability and sustainable communities, MIT Press: London, 2003.

[15] Kooiman, J., Governing as Governance, Sage Publications: London, 2003.

[16] Moulaert, F. \& Ailenei, O., Social Economy, Third Sector and Solidarity Relations: A Conceptual Synthesis from History to Present, Urban Studies 42(11), pp. 2037-2053, 2005.

[17] Fraisse, L., Ortiz, H. \& Boulianne, M., Solidarity Economy. Proposal Paper For the XXI century. Solidarity Socio-economy Workshop, http://ecosol.socioeco.org/documents/81pdf_fnl15en.pdf.

[18] Fisher, W.F. \& Ponniah, T., Another world is possible. Popular alternatives to globalization at the World Social Forum, Zed Books: London, 2003.

[19] Portes, L. \& Moreira, M., Cooperativas geram trabalho e renda; Maioria dos cooperados são mulheres, Diaro Oficial 8(453), pp. 3-5, 2004.

[20] Kooiman, J., Governing as Governance, Sage Publications: London, 2003. 
[21] Plummer, J., Municipalities and community participation: A sourcebook for capacity building, Earthscan: London, 2000.

[22] Argyris, C., Increasing Leadership Effectiveness, Wiley: New York, 1976.

[23] Tremblay, C., Community-based recycling initiatives in Vancouver, University of Victoria, Department of Geography, Master Thesis, 2007.

[24] Gutberlet, J., The Binning community in Victoria: A participatory exploration for livelihood enhancement, Human Resources and Skills Development Canada (HRSDC), 2007.

[25] Gowan, T., Excavating "globalization" from street level: homeless men recycle their pasts. Global Ethnography, Buravoy, M. et al., University of California Press: Berkeley, pp. 74-105, 2000.

[26] Arruda, M., Tornar o Real Possivel - A Formação do Ser Humano Integral: Economia Solidária, Desenvolvimento e o Futuro do Trabalho, PACS/Editora Vozes: Rio de Janeiro, 2006.

[27] Singer, P., As grandes questões do trabalho no Brasil e a economia solidária, Proposta, 30(97), pp. 12-16, 2003.

[28] Esteves, A.M.F., When Microfinance Promotes Mobilization: A case study within the Brazilian Movement of Solidarity Socio-economy. 12th International Conference on Alternative Futures and Popular Protest. Manchester Metropolitan University, 2007. 